Saeculum Christianum

vol. XXII (2015)

pp. $98-112$

MONIKA MICHALSKA*

Jagiellonian University, Kraków

\title{
THE STATE OF KNOWLEDGE ABOUT THE BEGINNINGS OF THE CISTERCIAN ABBEY IN HENRYKÓW IN HISTORIOGRAPHY OF THE LATE MIDDLE AGES RENAISSANCE
}

\section{Introduction}

The monastery foundations as an expression of piety and authority of the rulers as well as a sign of power of the Church played an important role in the vision of history created on the medieval and Renaissance historiographical cards. The pieces of information provided by chroniclers on the foundation process of individual monastic communities are often a valuable addition to the monastic foundation tradition.

In the case of the Cistercian monastery in Henryków that is interesting to us, the information flowing from the late medieval and Renaissance chronicles provides two concepts of the history of the abbey ${ }^{1}$. The first one, complying with the monastic vision of the beginnings, attributed the foundation of the abbey in Henryków to Silesian princes. The concept was proposed by the Brest canon Peter of Byczyna - the author of Chronica principum Poloniae ${ }^{2}$.

* Translated by Spektra Sp. z o.o.

1 The problem of the abbey in Henryków has been widely discussed in the literature on the subject: W. Pfizner, Versuch einer Geschichte des vormaligen Furstlichen Cisterziensers - Stiftes Heinrichau bei Munsterberg in Schlesien, pp. 69-78; Monasticon Cisterciense Poloniae, vol. 2, Katalog męskich klasztorów cysterskich na ziemiach polskich i dawnej Rzeczypospolitej, ed. A.M. Wyrwa, J. Strzelczyk, K. Kaczmarek, Poznań 1999, pp 65-77; H. Grüger, Heinrichau. Geschichte eines Schlesischen ziterzienserkloster 1227-1997, Köln 1978, p. 11-15; idem, Das Patronatsrecht von Heinrichau. zur 750-Jahrfeier der Klostergündung am 28. Mai 1977, „Cîteaux. Commentarii Cistercienses”, 28/1977, pp. 26-47; J. Mularczyk, Jeszcze raz o fundacji klasztoru w Henrykowie, in: Acta Universitatis wratislaviensis. Historia (hereinafter: AUWr), 33/1980, pp. 181-198; H. Dąbrowski, Uformowanie się wielkiej własności feudalnej cystersów w Henrykowie, „Roczniki Historyczne” 21/1956, pp. 109-149; M. Cetwiński, Bóg, szatan i człowiek w Księdze henrykowskiej, „Nasza Przeszłość”83/1994, pp. 85-95; A. Adamska, Founding a Monastery over Dinner: The Case of Henryków in Silesia (c. 1222-1228), in: Medieval Legal Process: Physical,Spoken and written Performance in the Middle Ages, ed. M. Mostert, P. Barnwell, Turnhout 2011, pp. 212--230; Górecki P., Pamięć, forma literacka a tworzenie przeszłości: opat Piotr z Henrykowa jako dziejopis $i$ doradca prawny, „Roczniki Dziejów Społecznych i Gospodarczych”, 60/2000, pp. 71-110; idem, An interpreter of Law and Power in a region of mediewal Poland: Abbot Peter of Henryków and his Book, in: Building legitimacy:political discourses and form of legitimac, ed. I. Alonso, J. Escalona, H. Kennedy, Lyon 2003, pp. 263-290; P. Wiszewski, Życie zakonne w oczach elity intelektualnej Ślasska średniowiecznego i nowożytnego. Przemiany pewnego motywu, AUWr 63/2003, pp. 183-216; idem, Zakonnicy i dworzanie - tradycje fundacji klasztorów w średniowiecznym dziejopisarstwie śląskim XIII-XV century, AUWr 153/2001, pp. 179-198.

2 Kronika książąt polskich(Chronica principum Poloniae), ed. Z. Węclewski, Monumenta Poloniae Historica (hereinafter:MPH), vol. III, Lwów 1878, pp. 425-578. 
The second concept, in which the title of the founder belonged to the notary Nicholas, was reflected on the pages of Annales seu cronicae incliti Regni Poloniae by Jan Długosz ${ }^{3}$. The indicated version became extremely popular in the Renaissance historiography and was continued in the works of: Maciej of Miechów Chronica Polonorum ${ }^{4}$, Marcin Kromer De origine et rebus gestis Polonorum libri $X X X^{5}$ and Joachim Cureus Gentis Silesiae Annales 6 .

The aim of the article is to present the transmission of knowledge on the foundation of the abbey in Henryków within the historiography from the end of the 14th century to the 16 th century. The analysis will cover both the problem of the expansion of knowledge on the Henryków Foundation and the aspect of its canonisation in the 16th century.

\section{The Founder}

The figure of the founder of the abbey in Henryków will constitute a starting point for our considerations. According to the monastic tradition, most completely reflected in the first part of the Book of Henryków written down by the abbot, Peter, in the second half of the 13th century, the abbey was established as a result of the intention of Nicholas, the notary of the prince, Henry the Bearded. Nicholas decided to earmark all his goods, obtained while providing the service to the prince, on behalf of the foundation? ${ }^{7}$. Henry the Bearded, asked to give his consent to the foundation, issued it with one reservation, namely, that the name of the founder would not be attributed to Nicholas, but to the princes, especially to his sonHenry the Younger, who was to be considered by the monks as the founder of the abbey ${ }^{8}$. The author of the second part of the Book of Henryków, written in the first half of the 14th century, also called Henry the Pious the true founder of the abbey ${ }^{9}$.

The Duke Register (Metryka Książęca) of the abbey in Henryków was kept by the author of the Chronicle of Polish Dukes: Hic Henricus merito potest eciam dici fundator fuisse cenobii apud Heinrichaw, quoniam et si non ipse tamen promocione ipsius nicolaus suus notarius idem fundavit monasterium, sicut narratur de eo ${ }^{10}$. However, Peter of Byczyna introduced a serious change - although he regarded Duke Henry as the founder of the abbey, he meant Henry the Bearded, contrary to the Book of Henryków. From the notes of the Chronicler, ending the whole fragment of sicut narratur de eo, one may deduce that the indicated information came from the oral tradition, probably the court of the dukes of Legnica and Brzeg, on whose commission Peter wrote the aforementioned work. The main patron of the chronicle, Duke Louis-the Duke of Legnica and Brzeg, propagated the cult of St. Hedwig of Silesia, and in his artistic and church foundations referred to the great past of

\footnotetext{
Ioannis Dlugossii Annales seu Cronicae incliti Regni Poloniae. Liber 5,6, ed. J. Dąbrowski, Warszawa 1973.

Maciej z Miechowa, Chronica Polonorum, Kraków 1521.

Marcin Kromer, De origine et rebus gestis Polonorum libri XXX, Bazylea 1555.

6 Joachim Cureus, Gentis Silesise annales, complectes historiam de orgine, praecipuorum euentuum, qui in Eccelesia \& recitationem vsque ad necem Ludouici, Hungariae \& Bohemiae regis, acciderunt, Wittenberga 1571.

7 Księga henrykowska, ed. R. Grodecki, Wrocław 1990.

8 Ibidem, pp. 5-12.

9 Ibidem, p. 59.

10 Kronika Książąt Polskich, MPH vol. III, p. 488.
} 
Silesia, unambigously connected with the figure of Henry the Bearded ${ }^{11}$. It is possible that the canon wanted to show some parallels between Henry the Bearded - the founder of the monasteries and Louis. Anyway, Henry the Pious as the founder of Henryków is present only in the monastic tradition. However, as early as in the 14th century the homogeneity of the tradition was broken within the monastery itself, Henry the Bearded was mentioned more and more often as the founder, as evidenced by the inscription from the monastery church dated to 1355: Anno Domini MCCXXVii Monasterium hoc. Ord. Cisterciens. fundatum est ab Henrico Duce Silesiae ex Testamento D. nicolai olim eiusdem Principis notarii ${ }^{12}$, and also a notation from the Henryków obituary dating back to the first half of the 14th century: 2 Xii Agetur anniversarium fundatorum huius monasterii, scilicet d. ducis Heynrici cum barba et filii eius necnon $d$. nicolai ${ }^{13}$.

It seems convincing, however, that the source of the concept which attributed the title of the founder to Henry the Bearded was Ordynacja Biskupów Wrocławskich (the Ordinance of Wrocław Bishops ${ }^{14}$, which constitutes a part of the Book of Henryków ${ }^{15}$. According to Roman Heck, Peter of Byczyna did not use the Book in his Chronicle but only the Ordinance $^{16}$. The use of the Ordinance by the chronicler is confirmed by the analysis of the content and form of De institucione ecclesiae wratislaviensis - the last part of the work by Peter of Byczyna ${ }^{17}$. Namely, according to the note from the catalogue of Henryków, the monastery was founded under Bishop Lawrence in 1227: sub pio duce Heinrico cognomine cum $b a r b a^{18}$. It is possible that the record, which was not preceded by an examination of the contents of the Book of Henryków, made Abbot Peter believe that the founder of the monastery had been Henry the Bearded.

On the other hand, one can see the foundation problem complexity in the chronicle of Peter of Byczyna, characteristic of the Book of Henryków. On one side - according to the

\footnotetext{
11 In the Lubin Code of the picture of St. Hedwig, which was commissioned by Duke Ludwig, Henry the Bearded was described as 'the Prince of the whole Silesia', which in the 14th century reality contrasted with the partition of Silesia into districts, thus showing the glorious past of the indicated district. In turn, in the foundation act of the Brest collegiate one can find information that the ruler's work was modelled on the deceased princes, with whom he was connected by family ties; See: A. Karłowska - Kamzowa, Fundacje artystyczne księcia Ludwika i Brzeskiego: studia nad rozwojem świadomości historycznej na Śląsk XIV-XVIII century, Wrocław 1970, p. 17 and pp. 93-95.

12 The inscription from the monastery in Henryków has been preserved only in a copy of modern historiographers, See: Excerpta ex nicolai Henelii ab Hennenfeld chronico ducatus Monsterbergensis et teritorii Francosteinensis, ed. F.W. Sommersberg, in: Silesiacarum rerum Scriptores, vol. 1, Breslau 1729, p. 142.

13 W.Wattenbach, Schlesische nekrologien, 1. nekrologium des Stifts Heinrichau, p. 302.

14 Full name: initium ordinationis wrat(izlaviensis) ecclesie episcoporum, quorum nomina libello presenti subscribuntur; Liber fundationis claustri Sancte Marie Virginis in Henrichow, ed. G.A. Stenzel, Breslau 1854, p. 123.

15 Księga henrykowska, pp. 99-106.

16 R. Heck, Kronika książąt polskich - metoda prezentacji dziejów, w: Dawna historiografia Ślaska. Materiały z sesji naukowej odbytej w Brzegu w dniach 26-27 listopada 1977 r., ed. K. Gajda, Opole 1980, pp. 61-81.

17 Cf.: Huius domini Laurentii episcopi tempore fundatum est claustrum nostrum de Heinrichow, anno domini MCCXXVii sub pio duce Heinrico, cognomine cum barbato. Eodem anno quinto kalendas Junii, intravit conventus hic in Henrichow (Liber fundationis claustri Sancte Marie Virginis in Henrichow, p. 126) oraz: cuius temporibus fundatum est monasterium Cisterciensis ordinis in Henrichow, per quedam nicolaum, qui dicitur fuise notarius domini Henrici cum barba, ducis wratislaviensis, cum adiutorio tamen eisudem domini sui duci. Conventus intravit idem monasterium sub duce predicto anno domini MCC XXII, V kalend. Juni (Kronika Książat Polskich, p. 547). One can see that after throwing out the fragment on Nicholas, both notes show a great convergence in terms of grammatical construction and order.
}

18 Liber fundationis, p. 126. 
author - the prince may be rightly regarded as the founder of the abbey, despite the fact that he did not establish the monastery himself. On the other side, the notary Nicholas, who, with the support of the prince, created the foundation, did not hold such a title. The descriptions of the Henryków and Trzebnica foundations are worth comparing. When it comes to the Trzebnica monastery, the information on the nuns' convent, be it in connection with the burials of the members of the duke's family or with the emotions that the Silesian Piast Dynasty had for the monastery, is provided by the chronicler several times on the pages of his work ${ }^{19}$. The author stresses the direct involvement and effort put by Henry the Beard in the foundation of the monastery in Trzebnica, in the fragment of the chronicle which is of interest to us: quod magno studio pietatis pridem fundaverat et large dotaverat ${ }^{20}$. The verbs in the third person singular fundaverat, dotaverat unambigously present the prince as a founder. In case of the abbey in Henryków, the author gave up personal forms in favour of the descriptive one: merito potest eciam dici fundator fuisse, which does not so strongly stress the role of the prince in the foundation of the abbey. Moreover, the phrase 'promotione ipsius', with no broader comment made by the chronicler, makes the data concerning Henryków raw, does not underline the prince's attitude to the foundation, just the way it happens in the case of Trzebnica.

The issue of the Henryków foundation returns once again, as we have already mentioned in De institucione, where the author states that the monastery was established by Nicholas with the help of Henry the Bearded ${ }^{21}$. However, the convent entered Henryków: sub duce predicto. It seems that the indicated fragment should be understood in the context of the first record concerning Henryków, namely, the one which said that Nicholas only implemented the foundation of the monastery and was not its legal founder.

Jan Długosz, who drew a great deal of information about Silesia from the work of Peter of Byczyna, both from the Chronicle of Polish Dukes itself and De institucione ${ }^{22}$ saw the problem regarding the foundation of the abbey in a completely different light. According to Długosz, undoubtedly, the founder of Henryków was the notary Nicholas: nicolaus siquidem de Henrichow ducis wrathislaviensis Henrici cum barba secretorum notarius [...], de consensu et annuentia ducis Heinrici cum barba in villa patrimoni sui Henrichov [...] monasterium ordinis Czistercziensis fundat $[\ldots]^{23}$. Nicholas met the conditions expected from the true founder: he established and endowed the monastery. Similar information was also provided by the Cracow canon in the Katalogu biskupów wrocławskich (the Catalogue of the Wrockaw Bishops ${ }^{24}$. The variety of roles played by both the prince and Nicholas in

\footnotetext{
19 Kronika książąt polskich, pp. 487-489.

20 Ibidem, p. 488.

21 Ibidem, p. 547.

22 A. Semkowicz, Krytyczny rozbiór dziejów polskich Jana Dlugosza (do roku 1384), Kraków 1887, p. 216. The locations of monastic communities in the works of Długosz were referred to by, inter alia: P. Szczaniecki, Dlugosz o Tyńcu, „Zeszyty Naukowe Uniwersytetu Jagiellońskiego. Prace Historyczne”, 76/1985, pp. 171-176; M. Starnawska, Wiadomości Długosza o templariuszach i joannitach, in: Kultura średniowieczna i staropolska. Studia ofiarowane Aleksandrowi Gieysztorowi w pięćdziesięciolecie pracy naukowej, ed. D. Gawinowa et al., Warszawa 1991, pp. 471476; B. Wojciechowska, Małopolskie klasztory cystersów w opinii Jana Dlugosza, in: Klasztor w kulturze średniowiecznej Polski, ed. A. Pobóg-Lenartowicz, M. Derwich, Opole 1995, pp. 195-200.

23 Ioannis Dlugossii Annales, p. 236.

24 Catalogus episcoporum wratislaviensium, in: Joannis Dlugossi Senioris Canonici. Opera omnia, ed. Alexander Przezdziecki, vol.1, Kraków 1887, p. 461.
} 
the establishment of the abbey completely disappears. The message conveyed by Długosz becomes one-dimensional, marginalising the figure of the duke for the benefit of Nicholas called felix fundator of Henryków ${ }^{25}$.

Maciej of Miechów ${ }^{26}$, Marcin Kromer ${ }^{27}$ and Joachim Curreus ${ }^{28}$ followed Długosz with no changes. Maciej of Miechów literally took the fragment concerning Henryków, without making any significant changes in the text of the author of the Annals. On the other hand, Kromer introduced mainly stylistic corrections: nicolaus Henrichovius [...], qui Henrico Barbato a secretis fuit, et ipse patrimonium suum omne Cistersiciensibus monachis, assentiente Henrico barbato donavit et extruncto ${ }^{29}$. The only visible change is the lack of definitions, i.e. founder, foundation, which was replaced by the verbs donare (give) and extruir (build). However, it is clear from the context of the whole message that for Kromer it was Nicholas who was the founder of the monastery in Henryków, which is not surprising, given the fact that he used mainly the information provided by Długosz to present the history of the Piast Poland. Cureus provided similar information about the foundation of the monastery in Henryków: nicolaus [...] cancellarius Heinrici Barbati [...] praedia sua, que habebat ditissima legavit ad cultum divinum, et extruxit coenobium amplium ${ }^{30}$.

\section{The role of Dukes}

Despite the fact that, as has been stated above, only the Chronicle of Polish Dukes keeps the metrics of the prince foundation of the abbey in Henryków, in each of the works analysed by us, the establishment of the abbey is associated with the person of Henry the Bearded. On the one hand, it is achieved by making reference to the information on the function of the prince notary performed by Nicholas and on the other hand, by locating the abbey establishment in the regnal years of the prince.

Peter of Byczyna included a fragment concerning Henryków in the paragraph devoted to the last years of the reign of Henry the Bearded, as well as to the prince's special piety, which manifested itself in the foundation of the Cystercian monastery in Trzebnica and the monk convent in Henryków. According to the author of the chronicle, Henry the Bearded was to support the efforts of Nicholas to establish the abbey of grey monks: tamen promocione ipsius nicolaus [...] idem fundavit monasterium ${ }^{31}$. A similar passage can be found in De institucione: nicolaus [...] cum adiutorio tamen eiusdem domini suis $d u c i^{32}$. According to the chronicler, the indicated support provided to the prince, not characterised in detail, was to be a factor determining the recognition of Henry the Bearded as the founder of the monastery. The

\footnotetext{
25 Ioannis Dlugossii Annales, p. 236.

26 A. Borzemski, Kronika Miechowity. Rozbiór krytyczny, Kraków 1890, p. 172.

27 L. Finkel, Marcin Kromer - historyk polski XVI wieku. Rozbiór krytyczny, Kraków 1883, p. 176; J. Radziszewska, warsztat naukowy Marcina Kromera w jego dziele „De origine et rebus gestis Polonorum”, in: Historia i współczesność. z zagadnień historiografii od czasów antyku do XVI wieku, ed. A. Kunisz, Katowice 1982, p. 131-162 .

28 M. Karpowska-Jarczyk, Wokół Gentis Silesiae annalis Joachima Cureusa. Z dziejów szesnastowiecznej historiografii śląskiej, Katowice 2011.

29 Marcin Kromer, De origine, p. 188.

30 Joachim Cureus, Gentis Silesise annales, p. 61.

31 Kronika Książąt Polskich, p. 488.

32 Ibidem, p. 547.
} 
Book of Henryków depicts the role of Henry I in a slightly different manner. Firstly, during the conversation conducted by Nicholas, Peter, the provost, and Idzi (Lat. Aegidius), the archdeacon, on the planned foundation, the notary observed that it was necessary to obtain the consent of the prince: domini mei ducis consensus ${ }^{33}$. Moreover, the description of the feast in Henryków in 1222 refers mainly to obtaining the duke's consent to the establishment of the monastery. The indicated task was entrusted to the bishops: Lawrence of Wrocław, Paul of Poznan and Lawrence of (Lubusz): Hic [Mikołaj] proponit, si tue benignitatis assuerit consensus [...] hoc in loco claustrum Griseorum tua auctoritate iniciare ${ }^{34}$.

Jan Długosz was closer to the records of the Book of Henryków. According to the Cracow canon, Nicholas created the foundation thanks to: consensu et annuentia Ducis Henrici cum barba ${ }^{35}$. However, the consent and authority given to the establishment of the abbey in Henryków by Nicholas constitute no argument for Długosz supporting the idea of recognising the duke as the founder of the monastery. Compared to the Chronicle of Polish Dukes (Chronica principum Poloniae), the duke's place in the history of the foundation is strongly limited. Despite mentioning the duke three times in the record (first, while defining Nicholas as a notary of Henry the Bearded, then in relations to the property obtained by Nicholas when he served with the duke and for the third time when the chronicler mentions the consent of the ruler to the foundation), it is the role of the ruler that is passive in the history of the foundation ${ }^{36}$. The figure of the duke Henry the Bearded serves primarily as a background to the activity of Nicholas, who as the duke's notary was closely associated with the ruler. It may stem from the location of the story on Henryków in the narration of the Annals. Due to the method adopted by Jan Długosz in the presentation of history, subjected to a chronological division into years, the passage concerning the abbey was separated from the history of the regnal period of Henry the Bearded, being placed within the same year as the establishment of the monastery in Kacice by Iwo Odrową $\dot{z}^{37}$. Additionally, Jan Długosz weakens the duke's position in the Catalogue of Bishops of Wrocław, by mentioning him in the note concerning Bishop Lawrence, only indirectly in the context of the office of Nicholas: notario Heinrici cum barba ${ }^{38}$.

On the one hand, one can speak on diminishing the role of dukes in the establishment of the abbey, on the other hand, however, thanks to Jan Długosz's reference to the figure of the Princess Hedwig, the importance of the duke's family grows in the process of the monastery foundation. Namely, on the example of the pious life and customs regarding Hedwig, who was totally devoted to God, Nicholas was inspired to establish an abbey ${ }^{39}$. While the Book of Henryków pointed to the impulse coming from God himself that ignited the desire in the heart of Nicholas to establish an abbey, in Długosz, God acted through the person of the Princess ${ }^{40}$. It is on the one hand connected with extremely high veneration in which

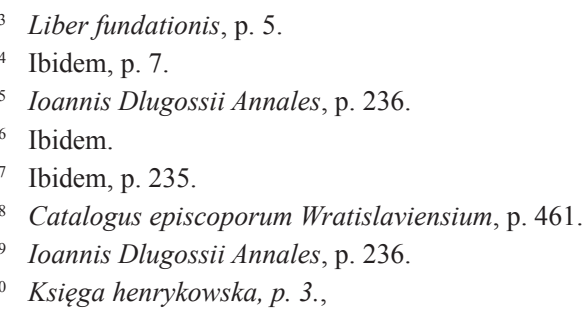


Długosz held the saints of the Polish nation, on the other hand, however, he was inspired by the Legend of St Hedwig.

Maciej of Miechów and Marcin Kromer quite faithfully recreated the relations between Henry the Bearded and the abbey in Henryków on the pages of their chronicles. The first one literally adopted the words of Długosz: de consensu et annuentia Ducis Heinrici ${ }^{41}$, whereas Kromer: assentiente Henrico Barbato ${ }^{42}$. Maciej of Miechów, however, got rid of the additions of Długosz, i.e. the inspiration of the notary, Nicholas, drawn from the pious deeds of the Princess Hedwig and the information on collecting the property by Nicholas while he was serving with the duke. Kromer omitted the latter information and replaced the element related to Hedwig's influence by a shortened phrase: Quod exemplum secutus nicolaus ${ }^{43}$, relating to the information preceding the description of the establishment of Henryków, namely to the foundation of Trzebnica by Henry the Bearded and his wife. While Maciej of Miechów, following Długosz, separated the story on Henryków from the history of reign of Henry the Bearded in favour of presenting the most important church foundations of the first half of the 13th century in one paragraph, Kromer placed the information on the foundation in the paragraph concerning the reign of Henry the Bearded, precisely at its end. On the one hand, he relates to the model presented in the Chronicle of Polish Dukes in this way, and on the other hand, it is the result of the conscious choice of conducting the lecture on the history by Kromer, who tried to order narrations ${ }^{44}$. Joachim Curreus, following the model of Długosz both in terms of the information and the layout of its content, introduced some changes and made additions. Primarily, the notion on the duke's consent to and approval of the establishment of the abbey in Henryków, presented by Curreus, disappers, which eliminates the role of Henry the Bearded in the establishment process. Curreus, however, talked a more honorary function of the prince who gave Nicholas, and some other men, inspiration to establish a monastery: imitatus pietatem sui Principis et multorum aliorum, qui tunc quasi certabant inter sese in condendis monasteriis ${ }^{45}$, which seems to be a transformation made by a historiographer of similar passages in Długosz, who mentioned the influence of Iwo Odrowąż and the princess Hedwig.

On the other hand, Curreus provides completely new information in comparison with earlier sources. Namely, Nicholas called the established monastery after the Duke Henry - Henryków: extruxit coenobium amplium, quod de nomine sui Principis appelavit Henrichovium $^{46}$. The indicated information is included only in the Book of Henryków: $o b$ reveranciam domini ducis antiqui appelavit totum Heinrichov ${ }^{47}$. The message provided by the Book relates mainly to the territory, whereas Cureus refers to the name of the monastery. It seems that the indicated information was drawn either from the oral tradition or it was his attempt to explain the etymology of the monastery's name. The thesis regarding the knowledge of the contents of the Book of Henryków seems to be rather less probable, as

\footnotetext{
41 Chronica Polonorum, p. 122.

42 De origine et rebus gestis Polonorum libri XXX, p. 188.

43 Ibidem.

44 J. Radziszewska, Warsztat naukowy, pp. 143-144.

45 Joachim Cureus, Gentis Silesise annales, p. 61.

46 Ibidem.

47 Liber fundationis, p. 17.
} 
it attributed the foundation of the monastery to dukes. Despite the fact that Cureus used a chronological layout of the text, which is confirmed by the title given to the work Gentis Sielesiae Annales, the foundation of the abbey in Henryków was assigned to the text fragment devoted to the reign of Henry the Bearded: Henricus Barbatus Princeps Silesiae, postea etiam Poloniae ethnarcha ${ }^{48}$.

\section{Nicholas}

The figure of Nicholas constitutes a central point in the story of the establishment of Henryków in all the sources quoted by us. The role of Nicholas was the only element that changed in the foundation process. The figure was either the cause of the establishment or the founder of the abbey. The two indicated ways in which the role thereof was perceived in the history of the abbey in Henryków impacted also the way in which authors characterised the figure of Nicholas as well as the amount of the collected date about him.

First of all, the function performed by Nicholas in the office of Duke Henry the Bearded was mentioned. Peter of Byczyna used the phrase which was the closest to the term appearing in the Book of Henryków and also in the documents from the regnal period of Henry the Bearded: Nicolaus notarius ${ }^{49}$, in Długosz we find secretorum notarius ${ }^{50}$, Maciej of Miechów uses the term: ducis notari ${ }^{51}$, Kromer: a secretis fuit ${ }^{52}$, and Cureus: cancellarius Henrici Barbati $^{53}$. Despite some minor changes in the title of Nicholas, all terms constitute a good reflection of the spectrum of his duties in the office of Duke Henry I.

None of the historians had mentioned Nicholas as a Wrocław canon until Joachim Cureus: Nicolaus [...], qui fuit canonicus wratislaviensis ${ }^{54}$. Similar information is provided by the Book of Henryków: quidem clericus nomine nicolaum ${ }^{55}$. The author of the Book of Henryków stressed the relations of Nicholas with the cathedral of St. John in Wrocław, in which he supposedly started his career at the side of the later bishop of Lubusz, Lawrence ${ }^{56}$. It should be added that the information on the canonicate of Nicholas is not included in any of the indicated documents. He was mentioned only as a notary on the preserved diplomas of the duke. Hence, it seems that Cureus had to draw the indicated information from the monks. There is an open question whether he used the Book or its 15th century summaries, placed on separate pages, which, similarly to Cureus, refer to Nicholas as the Wrocław canon first of all ${ }^{57}$. It should be observed that Cureus used the city archives as well as the monastery collection ${ }^{58}$ quite eagerly in his works, hence it is possible to claim that he used the information collected in Henryków.

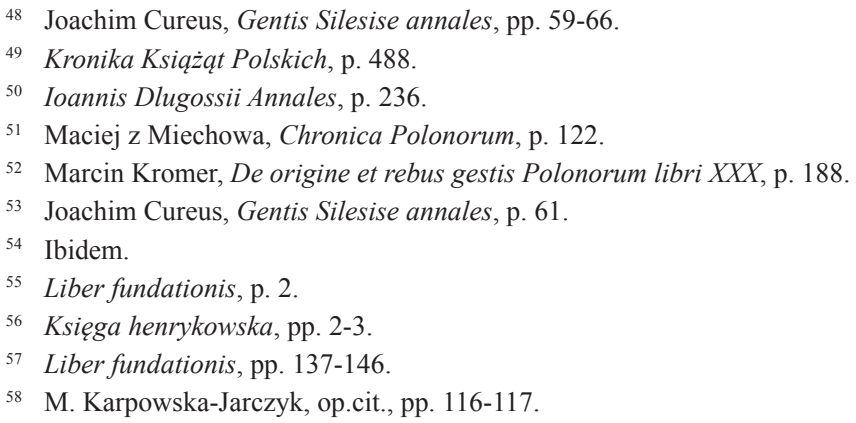


Jan Długosz undertook to assign personal features to the figure of Nicholas. Due to the fact that he had relatively modest data concerning Nicholas at his disposal, mainly through the chronicle of Peter of Byczyna, Długosz presented Nicholas as a man: genere et actione nobilis, which was a frequent expression used by the indicated historian with reference to the founders of church institutions. The chronicler revealed Nicholas also as a man who modelled himself on pious great men. Finishing the description of the monastery in Kacice by the Cracow bishop Iwo Odrowąż and moving on to the note made by Nicholas on the Henryków foundation, he added: sed neque in solo pontifice Cracoviensi ywone amor Deo viguisse conspectus est, quin etiam in aliorum cordibus flammam suae dilectionis accendit ${ }^{59}$, which inscribed in the moralistic and didactic goal of the Annals. Primarily, however, Nicholas tried to model the deeds of his princess - Saint Hedwig: Dominae suae ducisse sancte Hedwigis et conversatione edificatus et exemplo, quam calestii amore totam viderat mancipatam ${ }^{60}$. There were two parallels to St. Hedwig's Legend. Firstly, just like the Princess, who founded the Cistercian monastery in Trzebnica together with her husband, Nicholas founded Henryków. Secondly, Hedwig settled in the monastery, founded by herself after the death of her husband, just like Nicholas, who was insufficiently satisfied by the fact that he had given all his property to God and he himself started the convent life. It can therefore be said that Długosz located the figure of Nicholas in the context of the Legend of St. Hedwig, which provided the whole history of the foundation with a logical coherence. The information supplied by Długosz, was reflected in the works of successive historians with slight modifications. Maciej of Miechów presented the figure of Nicholas in an identical way as Długosz. He only removed a fragment concerning the inspiration by St. Hedwig and Iwo Odrowąż. Marcin Kromer called Nicholas: vir nobilis et locuples ${ }^{61}$. Moreover, he shortened and modified a bit the fragment related to modelling the notary Nicholas on the figure of St. Hedwig, including the whole message of Długosz in the words: Quod exemplum secutus, which was associated with the information on the foundation in Trzebnica by Henry the Bearded and St. Hedwig, which preceded the description of the abbey in Henryków ${ }^{62}$. It can therefore be said that Kromer slightly changed the meaning of the Annals because he separated the whole story about Nicholas from the Legend of St. Hedwig and also introduced Henry the Bearded, next to his wife, into the group of inspirers of Nicholas. Joachim Cureus defined the figure of Nicholas in short: homo nobilis ${ }^{63}$. Like Kromer, he also preserved a fragment on the drawing of inspirations by Nicholas, however, the figure of Hedwig totally disappeared from his story, being replaced by Henry the Bearded and: miltorum aliorum, qui tunc quasi certabant inter sese in candendis monasteriis ${ }^{64}$, which certainly refers to the note following the information on Henryków, regarding the foundation of the monastery in Świdnica by brothers from the Wierzbno family, and also refers to the mention of the influence of the pious foundations of Iwo Odrowąż $\dot{z}^{65}$.

\footnotetext{
59 Ioannis Dlugossii Annales, p. 236.

60 Ioannis Dlugossii Annales, p. 236.

${ }_{61}$ Marcin Kromer, De origine et rebus gestis Polonorum libri XXX, p. 188.

62 Ibidem.

63 Joachim Cureus, Gentis Silesise annales, p. 61.

64 Ibidem.

65 Ibidem.
} 
Jan Długosz was the first to try to explain the later life of the notary Nicholas after the establishment of the abbey in Henryków. Nicholas, not being satisfied with his pious deeds, decided: locum eciam ipsum spreto seculo ingressus, asumpto habitu, in ordine usque ad mortem felix fundator militavit ${ }^{66}$. The notary Nicholas, according to the author of the Annales, entered a convent, took on a habit of a monk and stayed in the convent until death. We had already suggested that the passage is connected with the story of St. Hedwig, on whom Nicholas modeled himself. The information on Nicholas taking on a habit and living in the monastery of Henryków until death cannot be confirmed by earlier sources. The Book of Henryków does not mention a word on the topic, even though a trace can be found in the mention made by the abbot Peter - the author of the first part of the Book, on the pious life of Nicholas: Sed licet vir iste non in religiositate aliqua exemplum vivendi preberet [...] videbatur interius ad instar cuiusdam margarite per quatuor angulos lucidissime fulgentis adornari $^{67}$. Moreover, the abbot Henry was to persuade Nicholas to agree to his burial within the walls of the monastery whereas, at the time of his death, the notary was provided with viaticum and other church sacraments by the abbot Henry ${ }^{68}$. The indicated fragments may suggest that the last days were spent by Nicholas in the monastery. Moreover, the documents of Bishop Thomas I of 1237 and 1263 include the expression quasi haberat capellanus eorum nicolaus $^{69}$. As Nicholas was a canon of Wrocław, probably with priestly ordination, it was possible that he performed priestly functions in the monastery. However, both documents are in the monastery copy book which, according to the previous studies on the Annales, was not used by Długosz.

The information about the end of Nicholas's life was accepted by all subsequent sources. Maciej of Miechów repeated the story of Długosz in detail. Kromer using a slightly different version in style wrote: ipse quoque ibi religionum professus, vitam peregit ${ }^{70}$, whereas Joachim Cureus provided new information on the end of Nicholas's life: Tandem cum sibi nondum satisfacerat, ipse etiam religionem illam, quae est Cisterciensium, ingressus est. Annotarunt alii, istum nicolaum quarto anno post in vita sua sacerdotali non vero monastica, emigrasse, sed in talibus non est res magni momenti ${ }^{71}$. The first sentence reveals an almost literal borrowing from Długosz. The second part includes new information regarding the fact that Nicholas died in the monastery after four years, and the corrected information provided by Długosz on the notary Nicholas as a monk. Namely, he was to die as a clergyman, not a monk. Cureus clearly underlined that he used additional sources: annotarunt alii.

At this point a certain digression should be made with reference to Nicholas as a monk. August Sartorius - a historiographer of the Cistercian monastery, recalled the information on taking religious vows by Nicholas ${ }^{72}$ in his work Cistercium bis-tertium, referring to the works of Caspar Jongelinus and Angel Manrique ${ }^{73}$. However, he consulted the matter with the

\footnotetext{
66 Ioannis Dlugossii Annales, p. 236.

${ }^{67}$ Liber fundationis, pp. 3-4.

68 Księga henrykowska, p. 11.

69 Schlesisches Urkundenbuch [dalej:SUB], hrsg. H. Appelt, W. Irgang, Köln- Weimar - Wien 1971 - 1993 , Vol. II, No. 136, vol. III, No. 448.

70 Marcin Kromer, De origine et rebus gestis Polonorum libri XXX, p. 188.

71 Joachim Cureus, Gentis Silesise annales, p. 61.

72 A. Sartorius, Cistercium bis - tertium seu Historia elogialis [...], pp. 1117- 1118, Praga 1700.

73 Ibidem.
} 
then prior of Henryków, Tobiasz Ackerman, who supposedly stated that: De Viri monachatu nil meminerint, illud solum innuentes, eundem non in monasterio, sed in coemiterio ecclesiae cathedralis wratislaviensis, uni canonicum, extiterat sepultum equiscere ${ }^{74}$. It seems that in the monastery itself the version about a monk, Nicholas, was known. Modern notes attached to the Book of Henryków provide the following information: etiam anno [1227.Footnote MM] obiit idem nicolaus Henrichovius, postquam quingenium vel sexenium in religione transegisset, oraz in eodem monasterio religionum professus, vitam peregit ${ }^{75}$. However, it is an almost literal repetition of a fragment of the chronicle of Marcin $\mathrm{Kromer}^{76}$.

As can be seen, the information did not leave the monastery of Henryków. It was first recalled by Długosz, and then repeated by the following historians. It may be assumed that Cureus used the monastery sources: the Book of Henryków or its summaries. The fact that Cureus referred to written sources constitutes evidence against looking for the source of the indicated information in the oral tradition found among the monks in Henryków. The indicated thesis is also confirmed by the length of time that Nicholas was supposed to live after the establishment of the abbey in Henryków - quarto anno post, which, if we take the year 1222 as a starting point, gives us approximately the year 1226/1227, which complies with the information from the Book of Henryków.

\section{Abbey emolument}

In the light of the abovementioned sources, the emolument of the abbey in Heryków was described in a very perfunctory way. Peter of Byczyna was not interested in the indicated subject at all. Only Długosz tried to fill the gap. According to the author of the Annales, Nicholas accumulated a considerable fortune serving with the Duke, Henry the Bearded, as a notary. He founded the abbey: in villa patrimonii sui Henrichov, and endowed it with: tam villa eadem, quam alias ad illum locum spectantibus dotat ${ }^{77}$. Compared to the description of the abbey in Trzebnica, or Kacice/Mogiła, it can be seen that the author did not have detailed information on the emolument which is manifested by a general statement that the abbey was endowed with many properties. The passage connected with the status of Henryków itself, seems to be interesting. Namely, Długosz claims that Henryków was the hereditary property of the notary ${ }^{78}$, which differs from the message conveyed by the Book of Henryków, in which Nicholas is presented as a newcomer from Małopolska, who collected the land by means of the acts of purchase and the duke's bestowals ${ }^{79}$. However, a contemporary source of the Henryków foundation: the document of Władysław Odonica of $1225^{80}$, presents the abbey in Henryków as a patrimonium. A question arises whether Długosz used the document of Odonica in which the duke endowed the lands in Nakło region to monasteries in Lubiąż and Henryków for colonisation, or whether it was the guess of the author, who found it probable

\footnotetext{
74 Ibidem.

75 Liber fundationis, p. 146.

76 Marcin Kromer, De origine et rebus gestis Polonorum libri XXX, p. 188: ipse quoque ibi religionum professus, vitam peregit.

77 Ioannis Dlugossii Annales, p. 236.

78 Ioannis Dlugossii Annales, p. 236.

79 Księga henrykowska, pp. 2-3.

80 SUB, Vol. I, No. 252.
} 
that Nicholas had endowed the monastery with his patrimonium. Due to the fact that Długosz does not mention this endowment in his Annals one should support the second possibility.

Maciej of Miechów made similar comments on the issue of the monastery's endowment. Similarly Marcin Kromer: et ipse patrimonium suum omne Cistersciensibus monachis [...] donavit $^{81}$. In turn Cureus did not mention the status of the lands of Nicholas in his Annals at all. He only mentioned quite laconically that the notary Nicholas: praedia sua, que habebat ditissima legavit ad cultum divinum ${ }^{82}$.

In connection with the information provided by Długosz on the hereditary status of Henryków, the chronicler referred to Nicholas as: de Henrichow ${ }^{83}$, whereas Marcin Kromer made it a nickname for the notary of Henry the Bearded, slightly in the Renaissance fashion: Nicolaus Henrichovius ${ }^{84}$. Only Peter of Byczyna and Joachim Cureus did not use similar terms.

\section{The Establishment Date}

One of the most interesting elements in the presentation of the history of Henryków is the date of its establishment. The Book of Henryków provides very accurate information on the indicated issue. As many as three dates appear on the pages of the Book: the year 1222, when the decision of the foundation of the abbey was made, 28 May 1227 - the arrival of the first monk convent and 6 June 1228 - the official founding of the monastery, as well as the consecration of the altars in the monastery church ${ }^{85}$.

Peter of Byczyna does not provide the exact date of the abbey establishment in the main course of the narrative of the Chronicle of Polish Dukes. However, in De institucione, there is a date of the arrival of the first convent to Henryków, located under the figure of bishop Lawrence: cuius temporibus fundatum est monasterium Cisterciensis ordinis in Henrichow, per quedam nicolaum, qui dicitur fuise notarius domini Henrici cum barba, ducis wratislaviensis, cum adiutorio tamen eisudem domini sui duci. Conventus intravit idem monasterium sub duce predicto anno domini MCC XXii, V kalend. Juni ${ }^{86}$. As can be observed, the day date of 28 May ( $\mathrm{V}$ calends of June) complies with the actual state, but the year date of 1222 is questionable. As the entry concerning bishop Lawrence shows almost identical similarity with the figure of that bishop from the Ordinance of bishops of Wroctaw, which is found in the Book of Henryków: Huius domini Laurentii episcopi tempore fundatum est claustrum nostrum de Heinrichow, anno domini MCCXXVii sub pio duce Heinrico, cognomine cum barbato. Eodem anno quinto kalendas Junii, intravit conventus hic in Henrichow ${ }^{87}$, it seems that the author made a mistake while using the catalogue of Henryków. Firstly, it is supported by the inclusion of the correct date and secondly, by the obvious imitation of the catalogue of Henryków. Despite the fact that the year 1222 appears

\footnotetext{
81 Marcin Kromer, De origine et rebus gestis Polonorum libri XXX, p. 188.

82 Joachim Cureus, Gentis Silesise annales, p. 61.

83 Ioannis Dlugossii Annales, p. 236.

84 Marcin Kromer, De origine et rebus gestis Polonorum libri XXX, p. 188

85 Księga henrykowska, pp. 9, 11.

86 Kronika Książąt Polskich, p. 547.

87 Liber fundationis, p. 126.
} 
in the history of the abbey establishment, it can be confused with the date of the abbey foundation rather than with the arrival of the first convent.

Determining the date of the monastery foundation generated many problems for the historians but also for the Cistercians themselves. The General Chapter of the Order tried to regulate the indicated problem by establishing the date of the foundation to be the moment of arrival of the first convent consisting of 12 brothers, headed by the Abbot ${ }^{88}$. However, the chronicler's use of the correct date suggests not so much Peter's conscious acceptance of the year 1222, better suited to the moment of the foundation (if the expression of the will to establish a monastery was to be accepted as the moment of its foundation), but rather a simple mistake. The remark of Odilo Schmidt is worth quoting. While analysing the Silesian catalogues of the Wrocław bishops, he indicated a similar mistake in the death date of bishop Cyprian ${ }^{89}$. Some of the catalogues instead of the date 1207 placed the information on his death under the year $1202^{90}$. The aforementioned mistake had huge importance for future messages on the abbey in Henryków. The same date was adopted by Zygmunt Różyc in his Cronica et numerus episcoporum wratislaviensium constituting a summary of the Chronicle of Polish Dukes. While describing the figure of Bishop Lawrence he added the fact concerning the foundation of Henryków: cuius temporibus fundatum est monasterium Heinrichau. A.D. $1222^{91}$.

Jan Długosz passively repeated the mistake of the Brest canon. Additionally, he removed the day date, included in the catalogue of Peter of Byczyna. The date of the foundation of Henryków was also included by Długosz in the logical sequence of events. The Cistercian monastery in Kacice was established in the same year by the Cracow Bishop Iwo Odrowąż, whose example was to influence the decision regarding the foundation of the monastery by the notary Nicholas: sed neque in solo pontifice Cracoviense ywone amor dei viguisse conspectus est, quin eciam in aliorum cordibus flammam suae dilectionis accendit ${ }^{92}$.

Maciej of Miechów traditionally quoted the date of the monastery foundation after Długosz. However, Marcin Kromer does not provide any date. As was mentioned earlier, the information on the foundation of the monastery in Henryków was placed in the paragraph related to the last regnal years of Henry the Bearded, between the foundation of the monastery in Trzebnica (1203), and the foundation of the Dominican monastery in Rybnik (between 1202 and 1211), while in the same paragraph, the author mentioned further foundations, which did not lead to the foundation date of Henryków ${ }^{93}$. Assuming that Kromer based the abovementioned part of his work mainly on the Annals of Długosz ${ }^{94}$, whereas in the other part of the note on Henryków, no information was changed, it may be concluded

\footnotetext{
88 W. Schulte, Die nachrichten der Cistercienser über Leubus, ,Zeitschrift des Vereins für Geschichte Schlesiens”, 33/1899, pp. 213-214, p. 222.

89 O. Schmidt, Untersuchungen zu den Breslauer Bischofskatalogen, Breslau 1917, p. 45. It is possible that the author misread the date of the year from the catalogue of Henryków. In the 13th century, number two was written down by means of an oblique line directed to the left and a caron (diacritic mark) over it. However, the shape of number seven resembled letter $\mathrm{v}$ turned upside down.

90 Ibidem.

91 Cronica et numerus episcoporum wratislaviensium, ed. W. Kętrzyński, MPH, vol. VI, Kraków 1893, p. 578.

92 Ioannis Dlugossii Annales, p. 236.

93 Marcin Kromer, De origine et rebus gestis Polonorum libri XXX, p. 188.

94 J. Radziszewska, Źródta Marcina Kromera do dzieła De origine et rebus gestis Polonorum libri XXX, „, Studia Warmińskie", 26/1989, p. 228.
} 
that no other source was available to him with regard to the date issue. A similar problem concerning the date of the abbey establishment in Henryków can be found in the work of Joachim Cureus. The Silesian historian noted that the abbey in Henryków was established in $1221^{95}$. However, he mentioned two events that took place therein. The first one referred to elementary disasters that struck the Polish lands and were to last for three more years: Anno 1221. et triennio proximo post dicitur in omnibus his regionibus favisse fames et pestilentia atrocissima ${ }^{96}$. The second message regarded the foundation of the monastery in Henryków: Eodem tempore quidam nicolaus [...] extruxit coenobium ${ }^{97}$. So, it is clearly seen that Cureus did not attribute the foundation of the monastery directly to the year 1221 because the indicated year not only concerned the plague and famine on the whole territory of Poland but it was also to last for three years, and the foundation of the monastery was to occur: eodem tempore, i.e. between 1221 and 1224 .

Comparing the distribution of annual information in the Annals of Jan Długosz, constituting one of the basic sources of information for the Silesian historiographer, it can be observed that Cureus combined several data in a single paragraph, which the author of the Annals included between the years 1221 and 1222. The Silesian historiographer collected the data on famine and plague that struck Polish lands under one year. Długosz mentioned them under the same year. Then he selected the information on the continuation of natural disasters from the note of the canon of Cacow concerning the creation of the parish church in Cracow in $1222^{98}$. In turn, directly under the year 1222 , Cureus included information which was unknown to Długosz on the Prussian expedition of Polish Dukes ${ }^{99}$. It can be assumed, therefore, that Cureus did not determine any new interpretation of the date of the monastery foundation. As for the attribution of the foundation of the abbey in Henryków to year 1221, the results of the research conducted by Leopold Janauschek should be briefly mentioned ${ }^{100}$. According to this research, the indicated date appeared particularly in modern historiographic works. However, the information was especially popularised by the works of the Cistercian historian Caspar Jongelinus.

For example, it should be added that the assignment of the establishment of the monastery in Henryków to the year 1221 may also be spotted in the Krzeszów provenience, inter alia, in the monastery chronicle from the second half of the 17 th century ${ }^{101}$, in which there is a record of a faithful copy of the relevant passage from the work of Jongelinus: notitia abbatarium ordinis cistertiensis ${ }^{102}$.

\footnotetext{
95 Joachim Cureus, Gentis Silesise annales, p. 61.

96 Ibidem.

Ibidem.

98 ioannis Dlugossii Annales, pp. 233, 235, 239.

99 Joachim Cureus, Gentis Silesise annales, p. 62.

${ }^{100}$ L. Janauschek, Originum Cisterciensium Tomus Primus in quo praemissis congregationum domiciliis adjectisque tabulis chronologico-genealogicis veterum abbatiarum a monachis habitatarum fundationes ad fidem antiquissimorum fontium primus descripsit, Wiedeń 1877, pp. 229-230.

${ }^{101}$ A State Archive in Wrocław, the acts of the Cistercian monastery in Krzeszów, the Chronicle of the monastery in Krzeszów from Henry the Pious, syg.1, p. 21.

${ }^{102}$ C. Jongelinus, Notitia abbatarium ordinis cistertiensis [...], Kolonia 1640, p. 53.
} 


\section{Recapitulation}

The analysed source material presented basically two concepts of the establishment of the abbey in Henryków. The first one represented by Peter of Byczyna attributed the title of the monastery founder to Prince Henry the Bearded, which was partly consistent with the Duke metrics of the foundation promoted in the abbey of Henryków itself. The second one, whose author was Jan Długosz, considered the notary Nicholas to be the founder of the abbey. In the late medieval and early modern history the concept of Jan Długosz prevailed ${ }^{103}$. Subsequent historiographers: Maciej of Miechów, Marcin Kromer and Joachim Cureus accepted the message conveyed by the Cracow chronicler with greater or smaller changes. As late as in the 17th century, the version of the establishment of the abbey in Henryków by the duke was restored by the historical compendia on the Cistercian monastery whose authors were: Manrique, Jongelinus, Sartorius, and also by the research work of Mikołaj Henele von Henenfeld.

\section{The State of Knowledge about the Beginnings of the Cistercian Monastery in Henryków in Historiography of the late Middle Ages and Renaissance Summary}

The cloister of Cistercians in Henryków possesses the complex founding traditions, both monastic and secular. The most complete vision of the origins of the monastery in Henryków gives us the Book of Henryków. The Book of Henryków delivers quite a complicated picture of the foundation. In the foundation of the cloister as many as three persons took part: the notary Nicholas, prince Henry the Bearded and Henry the Pious. According to the author of the first part of the Book of Henryków, the prince Henry the Pious was the only founder of the cloister. The analysis of late medieval and renaissance chronicles give us a quite different picture of its foundation. There are two leading concepts. The first sustained thesis of princely foundations. Its originator was Peter of Byczyna the author of the Chronica Principium Poloniae. The second concept was created by Jan Dlugosz, who ascribed the foundation of Henryków to the notary Nicholas.

Keywords: monastery in Henryków, historiography of the late Middle Ages and Renaissance, the Book of Henryków, transmission of knowledge

Note about the Author: Monika Michalska, a PhD student at the Institute of History of the Jagiellonian University, her research interests include the history the Cistercian Order in Poland, foundation traditions of cystercian monasteries in Silesia, the Book of henryków, the reception of historiographic works in Cistercian abbeys.

103 St. Cynarski, Uwagi nad problemem recepcji „Historii” Jana Dlugosza w Polsce XVi i XVii wieku,w: Dlugossiana: studia historyczne w pięćsetlecie śmierci Jana Dtugosza, ed. St. Gawęda, Kraków 1980, pp. 281-291. 